\title{
PAINFUL DIABETIC POLYNEUROPATHY (DPN)
}

\author{
Ante Jurjević \\ Department of neurology, \\ Clinical hospital center Rijeka, Croatia
}

\section{Summary}

Diabetic polyneuropathy represents mostly symmetrical damage of the peripheral nerves associated with diabetes mellitus.

Clinical picture depends on the duration of diabetes, glucose blood level and insulin use.

Distal symmetric polyneuropathy is the most common neuropathy of diabetes. It presents with sensory symptoms, paresthesiae and fingers pain in the hands and legs. Isolated forms of DPN are asymmetrical (focal or multifocal) and autoimmune form.

Key words: diabetic polyneuropathy; treatement.

\section{PREVALENCE}

Peripheral neuropathies represent the most common acquired disorders of the nervous system, and the diabetic neuropathy is the most represented. The rising global prevalence of type 2 diabetes mellitus will lead to a further rise in polyneuropathy, known to involve approximately $65 \%$ of all patients with diabetes. Of this $16 \%$ suffers from painful diabetic polyneuropathy.

\section{DIAGNOSTIC CRITERIA}

The diagnosis of DPN requires history taking and neurological examination. It must be concluded if patient suffers from diabetes or impaired glucose tolerance, and if other end-organ complications of diabetes, such as retinopathy or nephropathy persist. According to history of the patient it has to be learned if the onset is gradual and chronic, since subacute onset may suggest alternative cause. Moreover, it has to be found if sensory symptoms and findings are promi- 
nent (motor symptoms suggest alternative cause). Helpful information would be if skin ulcerations, retinal abnormalities and sings of possible autonomic symptoms or signs persist.

In algorithm glycemia records, hemoglobin and microalbuminuria has to be evaluated. In order to exclude other causes of polyneuropathy thyroid-stimulating hormone, B12, HIV serology must be preformed. Ancillary tests include autonomic testing and corneal confocal microscopy. Corneal confocal microscopy represents a novel noninvasive approach toward the early diagnosis of axonal damage.

Also, lumbar MRI should be performed if spinal stenosis is suspected.

The most important examination is electromyography of upper and lower limbs. It is gold standard in diabetic polyneuropathy. Electrophysiology is used to exclude carpal tunnel syndrome and ulnar neuropathy, plexopathies and other polyneuropathies.

Electromyography with a needle electrode is used to determine innervation sample, form of active potential and the presence of positive waves and fibrillations.

Motor nerve conduction testing is obligatory to perform in, at least 3 nerves, and to analyze distal latency, amplitude and evoked potential as well as analyze of sensory action potentials. Electromyography analyzes only the thicker myelinated fibers which constitute $25 \%$ of the peripheral nerve. Early detection of diabetic polyneuropathy is important for early treatment and delay of irreversible changes of peripheral nerves.

Painful diabetic polyneuropathy is very unpleasant sensory and emotional experience. Problems are greater when patient rests, they can be easily provoked and they usually appear during the night

Diabetic polyneuropathy disturbs the dream, reduces working energy and impairs quality of life. Chronic pain leads to depression. Therefore, special attention is required in treatment of painful symptoms.

\section{NEW MECHANISMS}

Pathogenesis of painful diabetic polyneuropathy is not clearly understood.

The polyol hypothesis has generated trials of aldose reductase inhibitors but with mixed results. Well described mechanisms include microangiopathy and hypoxia involving the peripheral nerve trunk, ganglia or spinal cord, oxidative and nitratitive stress from free radicals, deficiency of growth factors or their uptake and abnormal glycolisation of structural neuron proteins.

The impact of alpha-lipoic acid, an antioxidant compound, has been analyzed in several trials with significant improvement of neuropathy. 
The possible role of insulin in the pathogenesis of diabetic polyneuropathy has had less attention. The local administration of insulin achieved poor results. A novel prospect is the possibility of administering insulin intranasally an approach that can access the cerebrospinal fluid and has been used to treat other neurological conditions.

Intrathecal administration in rat experimental model indicated the trophic support of insulin on peripheral neurons.

C peptide, a cleaved portion of the insulin prohormone, is postulated to have independent actions on peripheral neurons. It was demonstrated in early clinical trials.

Interruption of advanced glycation endproducts - receptor for advanced glycation endproducts (AGE-RAGE) signaling is a novel examined strategy. Experimental studies using mice model showed that interruption of AGE-RAGE signaling would protect neurons from neuropathy.

\section{TREATMENT}

The treatment is based on tight glycemia regulation, physical therapy, kinesitherapy and symptomatic medical therapy.

According to the guidelines of European Neurological Society and also Croatian Neurological Society the treatment with antidepressants, antiepileptic drugs and opioids is recommended. Antidepressants and antiepileptic drugs have specific action on ion channels.

Antidepressants used in treatment include tricyclic antidepressants (TCAs) and selective serotonin norepinephrine reuptake inhibitors (SSNRIs). They act through mechanisms involving block of sodium channels.

Recommended antiepileptic drugs are: pregabalin and gabapentin. They act through calcium channels in afferent fibers and reduce release of neurotransmitters.

Opioids are used in acute phase of painful syndrome. However, the chronic use is controversial due to possibilities of creating habits. They inhibit pain in presynaptic and postsynaptic receptors in the dorsal horn.

Recommendations for treatment are as follows:

First-line treatment is treatment with antiepileptic drugs: gabapentin (1200$3600 \mathrm{mg} /$ day), and pregabalin (150-600 mg/day) and antidepressants from SNRI group: duloxetin (60-120 mg/day) and TCA: amitriptyline (10-60 mg/day). Second or third line represents treatment with lamotrigine (200-400 mg/day), SNRI and opioids: Tramadol (250-400 mg/day). 
In conclusion, treatment of diabetic polineuropathy today is based upon specific and selective blocking of ion channels. New approach toward the treatment of diabetic polyneuropathy involves AGE-RAGE pathway direct insulin signaling of neurons.

\section{References}

[1] Hossain P, Sachdev A, Malik RA. Early detection of diabetics peripheral neuropathy with corneal confocal microscopy. Lancet 2005; 366: 1340-1343.

[2] Barada A. Liječenje dijabetičke neuropatije. Neuropatska bol. Urednici: Fingler M, Braš M., Grafika d.o.o. Osijek 1906; 201-204.

[3] Zochodne DW. Diabetic polyneuropathy an update. Curr Opin Neurol2008,21: 527-533.

[4] Toth C, Brussee V, Mritnez J.A et al. Rescue and regeneration of injured peripheral nerve axones by intratechal insulin. Neuroscience 2006;139: 429-449.

[5] Toth C, Rong LL, Yang C et al. RAGE and experimental diabetic neuropathy. Diabetes 2008; 1002-1017.

[6] Sills GJ. The mechanisms of action of gabapentin and pregabalin. Curr Opin Pharmacol 2006; 6:108-113.

[7] Demarin V, Bašić-Kes V, Zavoreo I et al. Recommandations for neuropathic pain treatment. Acta Clin Croat 2008, 47: 181-191.

\section{Sažetak}

\section{Bolna dijabetička polineuropatija}

Dijabetička polineuropatija kao jedna od komplikacija dijabetesa melitusa klinički se manifestra kao simetrično oštećenje strukture i funkcije perifernih živaca. Stupanj oštećenja i klinička slika ovise o trajanju dijabetesa, terapiji koju bolesnici uzimaju te vrijednostima glukoze u krvi. Distalna simterična polineuropatija kao najčešća komplikacija dijabetesa klinički se prezentira senzornim simptomima, parestezijama i bolovima u prstima ruku i nogu. Izolirane forme disalne dijabetičke polineuropatije mogu biti i asimterične (fokalne i multifokalne) i autoimune forme.

Ključne riječi: dijabetička polineuropatija; liječenje. 